Sergii I. Azarov ${ }^{1}$, D. S. (Engineering), Senior research associate ORCID ID 0000-0002-9951-8867e-mail: azarov@kinr.kiev.ua

Oleksii S. Zadunaj ${ }^{2}, \mathrm{PhD}$, Head of the center

ORCID ID 0000-0001-8589-1604 e-mail: a.zadunaj@gmail.com

${ }^{1}$ Institute for Nuclear Research of NASU, Kyiv, Ukraine

${ }^{2}$ State Research Institute of Cybersecurity Technologies and Information Protection, Kyiv, Ukraine

\title{
ANALYSIS OF METHODOLOGICAL APPROACHES TO THE EVALUATION OF ECOSYSTEM SUSTAINABILITY
}

Summary. Stability is a fundamental quality of natural ecosystems. Ecosystem stability is one of the most significant indicators of the state of the environment. It represents the ability of the ecosystem in general and its components to successfully withstand negative externalities while maintaining not only its structure but also its functions. It can be considered as the invariance of a particular state of the ecosystem, as well as the ability to transition to any other state at present (static stability) and continuity of ecosystem development (dynamic stability). The notion of stability is closely related to the ability of an ecosystem to return to equilibrium after the termination of external influences that have brought it out of equilibrium and to the notion of stability. Stability does not always mean the ability to maintain an equilibrium ecosystem, although initially the phenomenon of stability was treated as such. It is well known that biological systems are characterized by a homeostasis and their stability is to maintain certain state parameters within a certain constant level. The principle in the transition from consideration of the technical system to the consideration of the ecosystem is that in the last deviation of the real development trajectories from the trajectory of the purpose occur by chance, and it is impossible to obtain accurate information about these deviations. And if the stability of a technical system can be asserted clearly by analyzing the differential equations that characterize the behavior of the system, then, for the most part, it is impossible to make the differential equations of ecosystem functioning. Therefore, conclusions about the stability or instability of an ecosystem can only be made with some probability. The article discusses methodological approaches to the determination of ecosystem stability. It is determined that today there is no agreed terminological unity on this issue. It is emphasized that the stability of ecosystems is largely determined by the level of development balance of its components ecological subsystems. It has been found that in order to assess the status of ecosystems, it is necessary to select a stability indicator for evaluating.

Keywords: ecosystem; trajectory; attractor; stability ecosystems; balance; selforganization; external influences

(C) С.I. Азаров, О.С. Задунай, 2020

ISSN: 2411-4049. Екологічна безпека та природокористування, № 2 (34), 2020 


\title{
C.I. Азаров ${ }^{1}$, О.С. Задунай²
}

${ }^{1}$ Інститут ядерних досліджень НАН України, м. Київ, Україна

${ }^{2}$ Державний науково-дослідний інститут технологій кібербезпеки та захисту інформації, м. Київ, Україна

\section{АНАЛІЗ МЕТОДИЧНИХ ПІДХОДІВ ДО ОЦНЮВАННЯ СТІЙКОСТІ ЕКОСИСТЕМ}

\begin{abstract}
Анотація. Стійкість $е$ фундаментальною властивістю природних екосистем. Стійкість екосистеми - один з найбільш значущих показників стану навколишнього середовища. Вона являє собою здатність екосистеми в иілому та ії складових частин успішно протистояти негативним зовнішнім чинникам, зберігаючи при цььому не тільки свою структуру, але й свої функції. Ïі можна розглядати як незмінність певного стану екосистеми, так $i$ як здатність переходу до будь-яких інших станів у даний час (статична стійкість) $i$ неперервність розвитку екосистеми (динамічна стійкість). Поняття стійкості тісно пов'язане із здатністю екосистеми повертатися в стан рівноваги після припинення зовнішніх впливів, які вивели ї̈ зі стану рівноваги, а також з поняттям стабільності. Стійкість не завжди означає здатність підтримки екосистемою рівноважного стану, хоча спочатку явище стійкості трактували саме так. Загальновідомо, щуо для біологічних систем характерне явище гомеостазу і їхн стійкість полягає в підтримщі певних параметрів стану в межах деякого постійного рівня. Принциповим у переході від розгляду технічної системи до розгляду екосистеми є те, що в останньої відхилення реальних траєкторій розвитку від траєкторії мети відбуваються випадково і отримати точну інформаџію про ичі відхилення неможливо. I якщо про стійкість технічної системи можна стверджувати однозначно, аналізуючи диференціальні рівняння, щзо характеризують поведінку системи, то здебільшого скласти диференціальні рівняння функиіонування екосистеми неможливо. Тому висновки про стійкість або нестійкість екосистеми можна робити тільки з певною імовірністю. В статті розглянуто методичні підходи до визначення стійкості екосистем. Визначено, що на сьогодні немає узгодженої термінологічної єдності в иььом питанні. Наголошується, що стійкість екосистем значною мірою визначається рівнем збалансованості розвитку ї̈ складових - екологічних підсистем. 3'ясовано, щзо для виконання оцінки стану екосистем необхідно обрати показник стійкості, за яким і буде проводитися оцінка.
\end{abstract}

Ключові слова: екосистема; траєкторія; атрактор; стійкість екосистем; рівновага; самоорганізація; зовнішні впливи

\section{Вступ}

Проблема стійкості є однією з ключових у всіх галузях науки і техніки. Теорія стійкості встановлює ознаки, за якими можна визначити, буде рух стійким чи не буде. Цими питаннями займалися багато видатних математиків та механіків: Ж.-Л. Лагранж, Пуассон, Ляпунов та інші [1-3]. Але вони розглядали лише частинні випадки рухів і для розв'язання задач застосовували нестрогі методи. В наукових публікаціях стійкість різних систем розглядається як здатність зберігати свою структуру і характер функціонування в просторі та часі при зміні умов зовнішнього середовища. 


\section{Аналіз методів стійкості руху та їх практичне застосування}

Уперше задачу про стійкість руху небесних тіл поставив Ж. Лагранж [1]. Він заклав основи теорії малих (лінійних) коливань, звівши деякі задачі теорії малих коливань до лінійних диференціальних рівнянь зі сталими коефіцієнтами. Ж. Лагранж вивів 3 диференціальних рівнянь вікових збурень інтегральне співвідношення, в якому деяка додатна квадратична функція збурень ексцентриситету й довготи перигелію залишається незмінною. Він довів також теорему про стійкість ізольованого положення рівноваги матеріальної системи, коли силова функція діючих на систему сил має максимум, сформулював теорему про стійкість стану рівноваги консервативної системи, яка відповідає мінімуму потенціальної енергії.

Стійкістю або нестійкістю характеризуються не тільки стани рівноваги, але будь-які фазові траєкторії. Стійкість руху по Пуассону припускає, що відповідна фазова траєкторія при $\mathrm{t} \rightarrow \infty$ не покидає обмеженої області фазового простору [2]. Перебуваючи в цій області нескінченно довго, вона неминуче буде повертатися в як завгодно малу околицю початкової точки. Часи повернення можуть відповідати періоду або квазіперіоду при регулярному русі, а можуть являти собою випадкову послідовність, якщо рішення відповідає режиму динамічного хаосу. Іншими словами: стаціонарний стан називається стійким, якщо малі відхилення не виводять систему занадто далеко $з$ околиці цього стаціонарного стану. Стаціонарний стан називається асимптотично стійким, якщо малі відхилення від нього з часом загасають. Стаціонарний стан називається нестійким, якщо малі відхилення 3 часом збільшуються. Сталий стаціонарний стан являє собою найпростіший тип атрактора. Крім цього, часто використовують менш суворий критерій, розуміючи стійкість як обмеженість рішення зверху і знизу, тобто стійкість по Лагранжу. Точка $\mathrm{x}_{0}$, а також вихідна 3 неї фазова траєкторія $\mathrm{x}(\mathrm{t})$ називаються стійкими за Лагранжем, якщо стан $\mathrm{x}(\mathrm{t})$ завжди, при всіх $\mathrm{t}>0$ залишається в деякій обмеженій області фазового простору. Інакше кажучи, існує така константа $\mathrm{R}$, що для всіх $\mathrm{t}>0$ маємо $\|\mathrm{x}(\mathrm{t})\|<\mathrm{R}$.

Запис $\|x(t)\|$ буде позначати, як правило, звичайну евклідову норму:

$$
\|x(t)\|=\sqrt{x_{1}^{2}+x_{2}^{2}+\cdots+x_{N}^{2}},
$$

де $\mathrm{x}_{1}, \mathrm{x}_{2}, \ldots, \mathrm{x}_{\mathrm{N}}-$ компоненти вектора $\mathrm{x}$.

Точка фазового простору - $\gamma$ називається $\omega$-граничною точкою фазової траєкторії $\mathrm{x}(\mathrm{t})$, якщо можна вказати таку послідовність моментів часу $t_{k} \rightarrow+\infty$, що $\lim _{k \rightarrow+\infty} x\left(t_{k}\right)=y$.

Аналогічно, точка $\mathrm{z}$ називається $\alpha$-граничною точкою, якщо можна вказати таку послідовність моментів часу $t_{k} \rightarrow-\infty$, що $\lim _{k \rightarrow \infty} x\left(t_{k}\right)=z$. Множина $\Omega_{\mathrm{x}}$ всіх $\omega$-граничних точок називається $\omega$-граничною множиною даної траєкторії, а множина $\Lambda_{\mathrm{x}}$ всіх $\alpha$-граничних точок $\alpha$-граничною множиною. Траєкторія х $(\mathrm{t})$ називається стійкою за Пуассоном, якщо кожна іiі точка $\epsilon \alpha$-граничною та $\omega$-граничною, тобто $x(t) \in \Omega_{x} \cap \Lambda_{x}$.

Вводячи визначення стійкості за Лагранжем та Пуассоном, ми говорили про властивості однієї, окремо взятої траєкторії. Ідея створення загальної теорії 
стійкості належить О.М. Ляпунову [3, 4]. Поняття стійкості за Ляпуновим характеризує траєкторію 3 погляду поведінки сусідніх траєкторій, що розташовуються в їі околиці.

Припустимо, що динамічна система $x=F(x)$ при старті з початкової точки $\mathrm{x}_{0}$ породжує траєкторію $\mathrm{x}(\mathrm{t})$. Розглянемо іншу траєкторію тієї ж системи $\mathrm{y}(\mathrm{t})$, стартова точка якої у близька до $\mathrm{x}_{0}$. Якщо обидві траєкторії залишаються близькими в будь-який наступний момент часу, то траєкторія $\mathrm{x}(\mathrm{t})$ називається стійкою за Ляпуновим.

Говорячи більш формально, траєкторія х(t) стійка, якщо для кожного, як завгодно малого додатного числа $\varepsilon$ існує таке $\delta>0$, що для будь-якої точки старту з $\delta$-околиці точки хо, тобто при $\left\|x_{0}-y_{0}\right\|<\delta$, маємо для всіх $\mathrm{t}>0$.

$$
\|x(t)-y(t)\|<\varepsilon .
$$

Більш сильна властивість - асимптотична стійкість. Траєкторія $\mathrm{x}(\mathrm{t})$ асимптотично стійка, якщо для кожного, як завгодно малого $\varepsilon>0$ існує таке $\delta>0$, що при $\left\|x_{0}-y_{0}\right\|<\delta$ маємо для всіх $\mathrm{t}>0$.

$$
\lim _{t \rightarrow+\infty}\|x(t)-y(t)\|=0 .
$$

Коли говорять лише про стійку траєкторію, то в більшості випадків мають на увазі стійкість за Ляпуновим.

Наочна ілюстрація стійкості за Лагранжем, Пуассоном і Ляпуновим наведена на рис. 1.
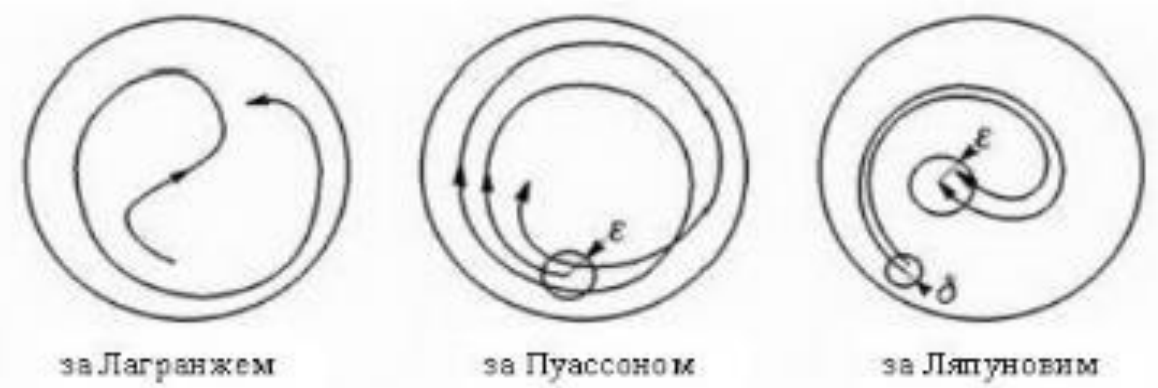

Рис. 1 - Якісна ілюстрація стійкості за Лагранжем (траєкторія залишається в замкнутій області), за Пуассоном (траєкторія багаторазово повертається в $\varepsilon$-околицю стартової точки) і за Ляпуновим (дві близькі на старті траєкторії залишаються близькими завжди) [4]

Спочатку вважалося, що ці основи стійкості руху можна застосовувати до простих фізичних систем, але подальші дослідження виявили, що ці підходи можна застосувати і до таких систем, як популяції, екосистеми і навіть до біосфери. Екосистеми - термодинамічно відкриті, функціонально цілісні системи, які існують за рахунок надходження з навколишнього середовища енергії і частково речовини та які саморозвиваються і саморегулюються. Загальний принцип стійкості екосистем можна висловити таким чином: «будь-які зовнішні впливи, що виводять екосистему зі стану рівноваги, 
викликають у цій екосистемі процеси, що намагаються послабити зовнішній вплив та повернути її в початковий рівноважний стан». Екосистеми у своєму природному розвитку хоч і спрямовані до рівноважного стану, але у такому стані існувати не можуть, а потребують додаткової енергії, яка забезпечується за рахунок дисипативних процесів. Математично зміни поведінки екосистем описуються нелінійними рівняннями. Ці процеси відбуваються як флуктуаційні зміни, що викликають турбулентність і можуть призвести до кризи або руйнування екосистеми.

Поняття стійкості в екології трактується неоднозначно, а відтак ії оцінку здійснюють за різними ознаками та проявами [5-7]:

1) вплив зовнішнього фактору чи групи факторів, відносно яких оцінюється стійкість;

2) відмінність екосистеми одного стану відносно іншого;

3) допустима величина відмінності від базового стану, тобто ії мінливість;

4) інтервал часу, в межах якого відбуваються зміни або оцінюється стійкість.

Однак механізми забезпечення, принципи та методи оцінки стійкості екосистем ще недостатньо розроблені. За аналогією з класичною механікою і теорією поля можна розглядати реакцію екосистеми на зовнішній вплив як динамічну зміну стану екосистеми, в процесі якої вона прагне мінімізувати деяку потенційну функцію. Залежно від конкретного виду екосистеми i прийнятих припущень така динаміка може бути локальною в сенсі руху екосистеми до відносного мінімуму, найближчого до поточного стану, або глобальною в сенсі руху до абсолютного (глобального) мінімуму відповідної потенційної функції, що наведено на рис. 2.

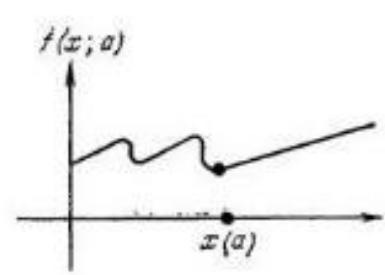

початок руху

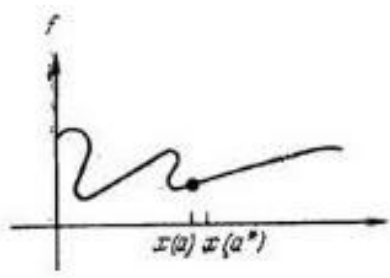

рух до локального мініму му

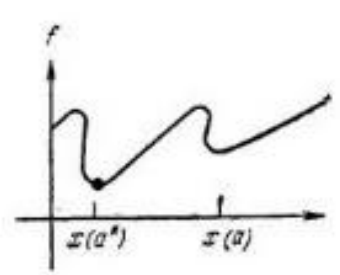

рух до глобального мінімуму

Рис. 2 - Опис екосистеми за допомогою потенційної функції, де $x(a)$ - початкове положення системи; $a$ - внутрішній параметр; f $x(a)$ - потенційна функція

Заміна параметра $a$ на $a^{*}$ призводить до зміни положення мінімуму функції f. Для екосистем, представлених безмежним числом постійно мінливих в часі процесів, цей вид стійкості може бути найбільш характерним. Для сталого за Ляпуновим руху мале початкове зрушення наростає. Якщо мале початкове зрушення не тільки не наростає, а з часом прагне до нуля, то рух має більш сильну схильність до асимптотичної стійкості. Позитивний максимальний показник Ляпунова є показником хаотичної динаміки, нульовий максимальний показник Ляпунова позначає граничний цикл або квазіперіодичну орбіту i негативний максимальний показник Ляпунова являє нерухому точку [4]. 
У складних екосистемах з підсистемами всередині систем, що входять в багаторівневу організацію, складно говорити про стійкість як деяку точку в просторі станів (як у випадку стійкості за Ляпуновим). Завжди необхідно враховувати ієрархію екосистеми i, відповідно, «ієрархію стійкостей»: очевидна локальна нестабільність може перебувати в області стійкості більш високого рівня. Стійкість в загальноприйнятому сенсі зазвичай має на увазі також здатність системи повертатися в попередній стан після обурення. Таким чином, для екосистем стійкість може розглядатися як здатність екосистеми реагувати (протидіяти) на зовнішні збурення. Такі області (безлічі), до яких прагнуть екосистеми 3 плином часу, називають атракторами. Іншими словами, атрактори - це сталі режими руху, тобто, безліч точок, область (у простому випадку - одна точка) у фазовому просторі екосистеми, до яких прагнуть іï траєкторії - вони ніби приваблюють, притягують траєкторії у фазовому просторі.

Атрактор є найважливішим поняттям, що фіксує специфіку дисипативних структур. Він визначається як режим (стан), до якого тяжіє екосистема. У змістовному плані це означає, що стан - атрактора виступає як пошуковий і досягається (у конкретній екосистемі) на фінальній фазі еволюції. Як зазначено в роботі [8], «якщо екосистема потрапляє в поле тяжіння певного атрактора, то вона неминуче еволюціонує до цього відносно стійкого стану (структури)». При вивченні процесів самоорганізації було зафіксовано обставину, що серед можливих гілок еволюції екосистеми далеко не всі $\epsilon$ вірогідними, «що природа не індиферентна, що в неї є «схильність до деяких станів», - у зв'язку з цим фізика «дисипативних екосистем, що виробляють ентропію», називає кінцеві стани цих систем атракторами.

Найважливішою обставиною в цьому контексті є той факт, що вказаний стан, до якого еволюціонує екосистема, виступає не тільки як потенційна перспектива iï розвитку, але і як реально дієвий фактор даного процесу. Фактично атрактор може бути розглянутий як фактор порядку (параметра порядку для екосистеми, що знаходиться в процесі самоорганізації) [9]. У динаміці відкритих систем виділяють три типи атракторів: стійкий фокус (атрактор-точка), стійкий граничний цикл і хаотичний, або дивний, атрактор. Стійким фокусом називається особлива точка, яка $є$ асимптотичною точкою всіх інтегральних кривих, що мають вид спіралей, вкладених одна в одну (рис. 3).
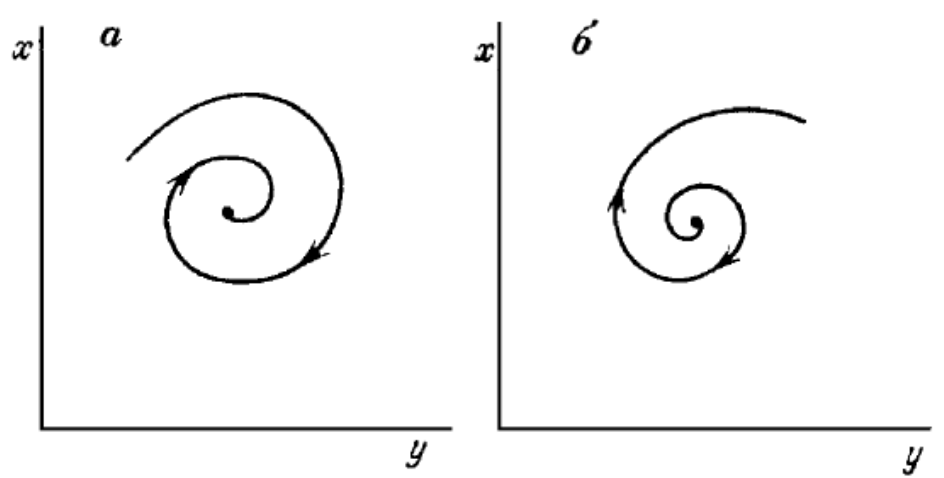

Рис. 3 - Стійкий (а) і нестійкий (б) фокус у фазовій площині (х, у) 
Можливі нестаціонарні стани екосистеми, тобто такі, в яких екосистема ще не в рівноважному стані. Наростання нелінійності в екосистемі за межі деякого критичного значення знову приводить екосистему до біфуркації: на зміну макроскопічній узгодженості приходить неузгодженість випадкових флуктуацій, яка призводить до неоднозначних результатів: мала зміна початкової умови з часом призводить до як завгодно великих змін динаміки екосистеми. У цій ситуації екосистема характеризується нестійкістю по відношенню до власних початкових параметрів (нестійкість за Ляпуновим) i експоненційною тенденцією до дивергенції. Такій поведінці екосистем був наданий термін динамічна. Така хаотична поведінка виникає не через зовнішні джерела шуму, або велике число ступенів свободи і не через невизначеність, пов'язану 3 квантовою механікою. Вона породжується власною динамікою нелінійної детермінованої екосистеми [10]. Визначальним для виникнення хаосу в детермінованих екосистемах є взаємодія елементів, які ії утворюють. У фазовому просторі такій поведінці екосистеми відповідає дивний атрактор. Детермінований хаос у фазовому просторі відображається безперервною траєкторією, що розвивається в часі без самоперетину (інакше процес замкнувся б в цикл) і поступово заповнює деяку область фазового простору. Таким чином, будь-яку як завгодно малу зону фазового простору перетинає нескінченно велика кількість відрізків траєкторії.

Це і створює в кожній зоні випадкову ситуацію - хаос. У такому випадку, незважаючи на детермінізм процесу, хід його траєкторії непередбачуваний, звідки і походить назва характеру процесу - детермінований хаос. Іншими словами, ми не в змозі передбачити або хоча б грубо охарактеризувати поведінку екосистеми на досить великому відрізку часу і в першу чергу тому, що принципово відсутні аналітичні рішення. Дана тенденція, однак, реалізує себе в межах досить чітко обмеженої сфери можливості.

Адже для таких екосистем можливий аж ніяк не будь-який стан, а лише стан, що потрапляє в обмежену детерміновану область фазового простору.

Оскільки нормальне функціонування екосистеми можливе лише при деякій нормі хаотичності, яка відповідає істотно нерівноважному стану, то відхилення в обидві сторони можна розглядати як «хворобу» i, отже, як деградацію. Однак, не завжди, особливо в екології, перехід до більш хаотичного стану слід розглядати як деградацію. Отже, істотним $є$ розгляд відхилень від норми хаотичності. Структури - атрактори еволюції, що розглядаються як цілісні структури, відносно прості в порівнянні зі складним ходом проміжних процесів, що формують їх.

На підставі цього істотно спрощується асимптотика і з'являється можливість прогнозування, «виходячи [11]:

a) «з цілей» процесів (структур-атракторів),

b) «від цілого», виходячи із загальних тенденцій розгортання процесів в цілісних екосистемах».

Для цього надскладна, безкінечно мірна, хаотизована на рівні елементів екосистема повинна описуватись, як і всяка нелінійна екосистема, невеликим числом фундаментальних ідей та образів, а згодом математичних моделей, що визначають загальні тенденції розвитку екосистеми. 


\section{Метод побудови фазових портретів екосистеми}

Дослідження еволюції станів складних систем за допомогою фазового простору широко застосовується в математичній екології і оцінюється як «найважливіший інструмент для формування наукових законів і наукового передбачення в екології». Еволюцію екосистеми часто представляють в деякому абстрактному просторі станів, який отримав назву фазового та в якому координатами служать компоненти стану. Кожному можливому стану системи відповідає точка фазового простору. Сутність поняття фазового простору полягає в тому, що стан як завгодно складної екосистеми представляється у ньому однією єдиною точкою, а еволюція екосистеми переміщенням цієї точки. Сукупність точок у фазовому просторі, положення яких відповідає станам екосистеми в процесі зміни у часі, називається фазовою траєкторією. Сукупність фазових траєкторій за різних початкових значень змінних дає легко доступний для огляду портрет екосистеми. Побудова фазового портрета дозволяє зробити висновки про характер змін екосистеми без знання аналітичних рішень вихідної системи рівнянь, що описують еволюцію екосистеми. Окремим випадком фазового простору $\epsilon$ фазова площина - координатна площина, в якій по осях координат відкладаються будь-які дві змінні (фазові координати), що однозначно визначають стан екосистеми. Координати фазового простору обираються в залежності від мети аналізу. Залежно від координат, що утворюють фазовий простір, розрізняють динамічний i параметричний фазовий простір. У динамічному фазовому просторі по одній з осей відкладають значення якої-небудь змінної, а на іншій першу похідну, або швидкість зміни в часі цієї змінної. Параметричний фазовий простір будується на осях незалежних змінних.

Для дослідження динаміки параметрів продукційно-деструкційних процесів за даними польових спостережень будувалися фазові портрети. 3 цією метою були використані динамічні фазові площини, параметричні фазові площини і тривимірний динамічний фазовий простір. Іншими словами, аналіз динаміки продукційно-деструкційних процесів проводили у фазовому просторі, що дозволив представити якісну картину зміни станів екосистем за їх фазовими портретами, не вдаючись до математичного моделювання.

\section{Оцінка показників стійкості в теорії нелінійних екосистем}

Важливим поняттям динамічних систем $є$ атрактор. Для екосистем, що знаходяться в положенні рівноваги, атрактор являє собою точку (зі зміною часу їх стан не змінюється), для коливальних екосистем - замкнуті траєкторії (цикли). Для хаотичних екосистем існує атрактор, який називається дивним, в цьому випадку траєкторії стягуються, але не в точку, криву, тор, а в деяку підмножину фазового простору. Атрактор є інваріантною характеристикою екосистеми, тобто зберігається під дією перетворень. Стійкістю і нестійкістю характеризуються не тільки стан рівноваги, але будь-які фазові траєкторії. У динаміці відкритих систем виділяють три типи атракторів: стійкий фокус (атрактор-точка), стійкий граничний цикл і хаотичний, або дивний атрактор.

Однозначними характеристиками хаотичності сигналу є спектр показників Ляпунова. Позитивний максимальний показник Ляпунова $\epsilon$ показником хаотичної динаміки, нульовий максимальний показник Ляпунова позначає 
граничний цикл або квазіперіодичну орбіту i негативний максимальний показник Ляпунова являє собою нерухому точку. Екосистема розмірності $\mathrm{n}$ має $\mathrm{n}$ показників Ляпунова: $\lambda_{1}, \lambda_{2}, \ldots, \lambda_{\mathrm{n}}$, упорядкованих за зменшенням. Динамічні екосистеми, для яких n-мірний фазовий об'єм зменшується, називаються дисипативними. Якщо фазовий об'єм зберігається, то такі екосистеми носять назву консервативних. У консервативних екосистем завжди існує хоча б один закон збереження. Наявність закону збереження часто спричиняє існування відповідного йому нульового показника Ляпунова. Для дисипативних динамічних екосистем сума показників Ляпунова завжди негативна. У дисипативних екосистем показники Ляпунова інваріантні щодо всіх початкових умов. За показниками Ляпунова можна багато чого сказати про динамічні системи, про розмірності атрактора, якщо такий $\epsilon$, i про ентропію динамічної екосистеми. Динамічному хаосу відповідає нестійкість кожної окремої траєкторії, тобто наявність хоча б одного позитивного показника Ляпунова. Тяжіння до атрактора вимагає, щоб фазові обсяги великих розмірностей стискалися, що й відображено в ляпуновському спектрі. Знання показників Ляпунова дозволяє оцінити і фрактальну розмірність атрактора.

Розглянемо точку $\mathrm{x}\left(\mathrm{t}_{0}\right)$, приналежну атрактору деякої динамічної екосистеми в початковий момент часу $\left(\mathrm{t}_{0}\right)$. Задавшись деяким малим позитивним числом $\varepsilon\left(\mathrm{t}_{0}\right)$, виберемо на атракторі ще одну точку $\mathrm{X}\left(\mathrm{t}_{0}\right)$ таким чином, щоб

$$
\left\|\mathrm{X}\left(\mathrm{t}_{0}\right) \tilde{x}-\mathrm{x}\left(\mathrm{t}_{0}\right)\right\|=\varepsilon\left(\mathrm{t}_{0}\right)
$$

Через проміжок часу $\Delta \mathrm{t}$ точки $\mathrm{x}\left(\mathrm{t}_{0}\right)$ та $\mathrm{X}\left(\mathrm{t}_{0}\right)$ еволюціонують відповідно в $\mathrm{x}(\mathrm{t})$ i $\tilde{\mathrm{x}}(\mathrm{t})$, відстань між ними позначимо через $\varepsilon(\mathrm{t})$, де $\mathrm{t}=\mathrm{t}_{0}+\Delta \mathrm{t}$ (рис. 4).

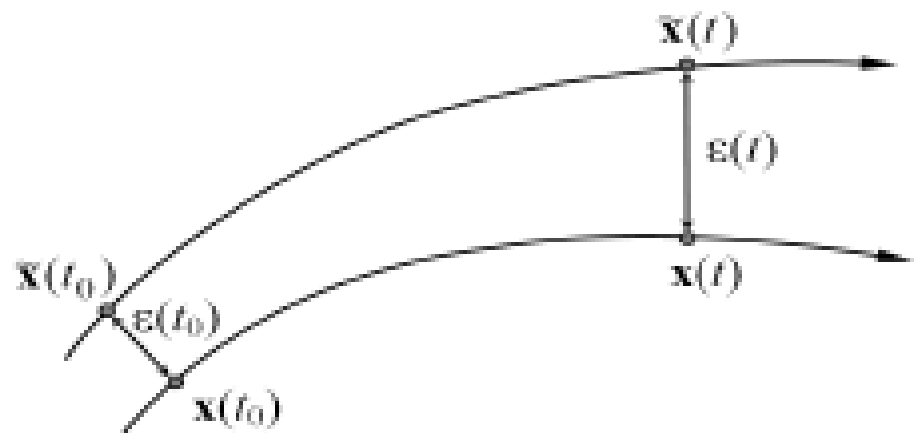

Рис. 4 - До визначення поняття експоненти Ляпунова

Очевидно, що $\varepsilon(\mathrm{t})$ залежить від положення точок $\mathrm{x}(\mathrm{t})$ i $\tilde{\mathrm{x}}(\mathrm{t})$, проміжку часу $\Delta \mathrm{t}$ i, звичайно, властивостей самої динамічної екосистеми. Однак, спрощено, можна вважати, що

$$
\varepsilon(t) \cong \varepsilon\left(t_{0} e^{\lambda \Delta t}\right)
$$

де $\lambda$ - параметр, що характеризує динамічну екосистему і називається старшим показником Ляпунова або експонентою Ляпунова. 
Після елементарних перетворень отримаємо:

$$
\lambda \cong \frac{1}{\Delta t} \ln \frac{\varepsilon(t)}{\varepsilon\left(t_{0}\right)} .
$$

Відразу необхідно зробити два зауваження:

- по-перше, в останньому співвідношенні, в силу обмеженості атрактора (а значить обмеженості $\varepsilon(\mathrm{t})) \Delta \mathrm{t}$ має зростати до тих пір, поки $\varepsilon(\mathrm{t})$ істотно менше розмірів атрактора, інакше $\lambda$ буде дорівнювати нулю, при $\Delta \mathrm{t} \rightarrow \infty$;

- по-друге, обчислене відповідно до (6) значення $\lambda$ слід розглядати як усереднене за всіма початковими точками $\mathrm{x}\left(\mathrm{t}_{0}\right)$ атрактора екосистеми.

3 урахуванням цих зауважень можна чітко визначити старший показник Ляпунова співвідношенням:

$$
\lambda=E_{\mathrm{x}\left(t_{0}\right) \in \mathrm{A}}\left\{\lim _{\substack{\Delta t \rightarrow \infty \\ \varepsilon(t)<\operatorname{diam} A}} \frac{1}{\Delta t} \ln \frac{\varepsilon(t)}{\varepsilon\left(t_{0}\right)}\right\},
$$

де $\mathrm{A}$ - атрактор екосистеми, diam $\mathrm{A}$ - його діаметр, а $\mathrm{E}\{\bullet\}$ - математичне очікування.

Старший показник Ляпунова характеризує ступінь експоненціальної розбіжності близьких траєкторій. Наявність у екосистеми позитивної експоненти Ляпунова свідчить про те, що будь-які дві близькі траєкторії швидко розходяться 3 плином часу, тобто має місце чутливість до значень початкових умов. Тому визначення експоненти Ляпунова дозволяє ідентифікувати динамічну екосистему 3 точки зору присутності в ній хаотичної поведінки. Екосистемам властива періодична зміна різних характеристик. В даному випадку періодична зміна величин являє собою один 3 типів стаціонарної поведінки екосистеми. Якщо коливання в екосистемі мають постійні період і амплітуду, встановлюються незалежно від початкових умов і підтримуються завдяки властивостям самої екосистеми, а не внаслідок впливу періодичної сили, екосистема називається автоколивальною. У фазовому просторі такому типу поведінки відповідає атрактор з граничним циклом. Граничний цикл є ізольована замкнута крива на фазовій площині, до якої в межі $\mathrm{t} \rightarrow \infty$ прагнуть всі інтегральні криві. Граничний цикл представляє стаціонарний режим 3 певною амплітудою, що не залежить від початкових умов, а визначається тільки організацією екосистеми.

Граничний цикл називається стійким, якщо існує така область на фазовій площині, що містить цей граничний цикл, - околиця $\varepsilon$, де всі фазові траєкторії, що починаються в околиці $\varepsilon$, при $\mathrm{t} \rightarrow \infty$ асимптотично наближаються до граничного циклу. Якщо ж, навпаки, в як завгодно малій околиці $\varepsilon$ граничного циклу існує принаймні одна фазова траєкторія, що не наближається до граничного циклу при $\mathrm{t} \rightarrow \infty$, то такий граничний цикл називається нестійким. Стійкі та нестійкі граничні цикли наведені на рис. 5.

Отже, встановлено, що атрактори типу фокусу i граничного циклу характеризують нерівноважний порядок. Поведінка екосистеми, відповідної граничному циклу, має характерну специфіку: малі збудження не руйнують іiі стаціонарного руху [9]. 


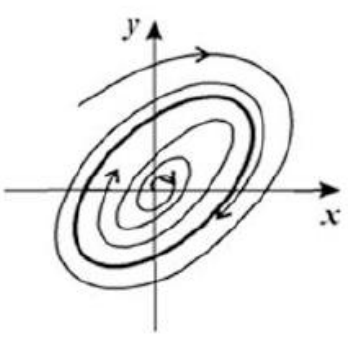

$a$

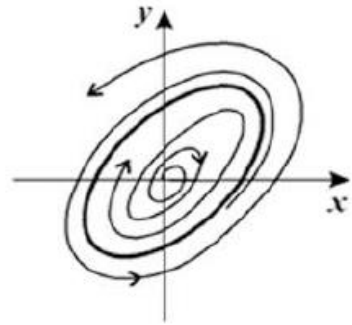

б

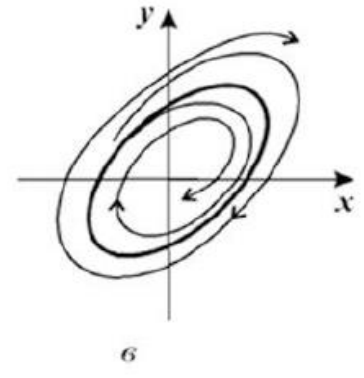

Рис. 5 - Стійкий граничний цикл (а); нестійкі граничні цикли (б, в)

\section{Висновки}

Успіх пошуку придатної функції Ляпунова в галузі екології найчастіше забезпечується інтуїцією і досвідом дослідника, ніж відомими рекомендаціями теорії. Тому, незважаючи на значний прогрес, досягнутий в останні десятиріччя, проблема узагальнення та модифікації методу Ляпунова з метою розширення множини придатних функцій залишається актуальною.

За допомогою функції i функціоналів Ляпунова вдається отримати ефективні критерії стійкості в цілому, у середньому, за постійно діючих збурень, практичної стійкості, стійкості на скінченому проміжку часу, а також інших типів стійкості. Метод Ляпунова є основним універсальним засобом дослідження стійкості в екосистемах. Однак практична побудова придатної функції чи функціонала Ляпунова для конкретного рівняння може виявитися дуже складною. У даній роботі на основі нових підходів запропоновані достатні умови стійкості і нестійкості, що допускають більш широкий клас придатних функцій i функціоналів Ляпунова в порівнянні 3 відомими методами. У такий спосіб удається полегшити дослідження стійкості конкретних динамічних процесів.

\section{СПИСОК ЛІТРАТУРИ}

1. Лагранж Ж. Аналитическая механика / Ж. Лагранж. - М.-Л.: Гостехиздат, 1950. T.1. -594 c.; Т.2. -440 c.

2. Зубов В.И. Аналитическое представление движений, устойчивых по Пуассону // Докл. РАН. 1992. Т. 322. № 1. С. 28-32.

3. Ляпунов А.М. Общая задача устойчивости движения / А.М. Ляпунов- М.-Л.: ОНТИ, 1935. - 368 с.

4. Зубов В.И. Устойчивость движения (методы Ляпунова и их применение). М.: Высшая школа, 1984. - 232 с.

5. Гродзинський М.Д. Стійкість геосистем до антропогенних навантажень. - Київ: Лікей, 1995. - $233 \mathrm{c.}$

6. Дідух Я.П. Поняття про стійкість екосистем // Основи біоіндикації. - К. : Наук. думка, 2011. - С. 288-297.

7. Матвеєва І.В. Стійкість екосистем до радіаційних навантажень / І.В. Матвеєва, С.І. Азаров, Ю.О. Кутлахмедов, О.В. Харламова. - К.: НАУ, 2016, 396 с.

8. Азаров С.І. Визначення надійності екосистем до чинника антропогенного тиску / Азаров С.I., Сидоренко В.Л., Задунай О.С. // «Екологічна безпека та природокористування», 2017, № 3-4 (24), - С. 50-57. 
9. Азаров С.I. Моделювання стійкості екосистеми / Азаров С.I., Задунай О.С. // «Екологічні науки». - 2018. - № 4 /2018 (23). - С. 5-9.

10. Margalef R. Perspectives in Ecological Theory / R. Margalef - Chicago: Univ. Chicago Press, 1968. - 198 p.

11. Азаров С.І., Задунай О.С. Моделювання еволюції нелінійних екосистем // «Екологічна безпека та природокористування», 2019 - № 2 (30), - С. 18-29. doi:http://dx.doi.org/10.32347/2411-4049.2019.2.18-29

Стаття надійшла до редакиії 16.01.2020 і прийнята до друку після рецензування 27.03.2020

\section{REFERENCES}

1. Lagranzh, ZH. (1950). Analiticheskaya mekhanika [Analytical mechanics]. M.-L.: Gostekhizdat. (in Russian)

2. Zubov, V.I. (1992). Analiticheskoye predstavleniye dvizheniy, ustoychivykh po Puassonu [Analytical representation of Poisson stable motions]. Dokl. RAN, 322(1), 28-32. (in Russian)

3. Lyapunov, A.M. (1935). Obshchaya zadacha ustoychivosti dvizheniya [The general problem of stability of motion]. M.-L.: ONTI. (in Russian)

4. Zubov, V.I. (1984). Ustoychivost' dvizheniya (metody Lyapunova i ikh primeneniye) [Stability of motion (Lyapunov methods and their application)]. M.: Vysshaya shkola. (in Russian)

5. Hrodzyns'kyy, M.D. (1995). Stiykist' heosystem do antropohennykh navantazhen' [Resistance of geosystems to anthropogenic loads]. Kyiv: Likey. (in Ukrainian)

6. Didukh, YA.P. (2011). Ponyattya pro stiykist' ekosystem [The concept of ecosystem sustainability]. In Osnovy bioindykatsiyi (pp. 288-297). K.: Nauk. dumka. (in Ukrainian)

7. Matveyeva, I.V., Azarov, S.I., Kutlakhmedov, YU.O., \& Kharlamova, O.V. (2016). Stiykist' ekosystem do radiatsiynykh navantazhen' [Resistance of ecosystems to radiation loads]. K.: NAU. (in Ukrainian)

8. Azarov, S.I., Sydorenko, V.L., \& Zadunay, O.S. (2017). Determination of the reliability of ecosystems to the factor of anthropogenic pressure. Ekolohichna bezpeka ta pryrodokorystuvannya, 3-4(24), 50-57. (in Ukrainian)

9. Azarov, S.I., \& Zadunay, O.S. (2018). Modelyuvannya stiykosti ekosystemy [Modeling ecosystem sustainability]. Ekolohichni nauky, 4(23), 5-9. (in Ukrainian)

10. Margalef, R. (1968). Perspectives in Ecological Theory. Chicago: Univ. Chicago Press. 11. Azarov, S., \& Zadunaj, O. (2019). Modeling of evolution nonlinear ecosystem. Environmental Safety And Natural Resources, 30(2), 18-29. doi:http://dx.doi.org/10.32347/2411-4049.2019.2.18-29 (in Ukrainian)

The article was received 16.01.2020 and was accepted after revision 27.03.2020

\section{Азаров Сергій Іванович}

доктор технічних наук, старший науковий співробітник, провідний науковий співробітник Інституту ядерних досліджень НАН України

Адреса робоча: 03680 Україна, м. Київ, пр-т Науки, 47

ORCID ID 0000-0002-9951-8867 e-mail: azarov@ kinr.kiev.ua

\section{Задунай Олексій Сергійович}

кандидат технічних наук, начальник центру Державного науково-дослідного інституту технологій кібербезпеки та захисту інформації

Адреса робоча: 03142 Україна, м. Київ, вул. М. Залізняка, 6

ORCID ID 0000-0001-8589-1604 e-mail: a.zadunaj@gmail.com 